Marquette University

e-Publications@Marquette

College of Nursing Faculty Research and

Publications

Nursing, College of

$10-2015$

\title{
Bidirectional Psychoneuroimmune Interactions in the Early Postpartum Period Influence Risk of Postpartum Depression
}

\author{
Elizabeth J. Corwin \\ Emory University \\ Kathleen Pajer \\ Dalhousie University \\ Sudeshna Paul \\ Emory University \\ Nancy Lowe \\ University of Colorado at Denver and Health Sciences Center \\ Mary Weber \\ University of Colorado at Denver and Health Sciences Center
}

See next page for additional authors

Follow this and additional works at: https://epublications.marquette.edu/nursing_fac

Part of the Nursing Commons

\section{Recommended Citation}

Corwin, Elizabeth J.; Pajer, Kathleen; Paul, Sudeshna; Lowe, Nancy; Weber, Mary; and McCarthy, Donna O., "Bidirectional Psychoneuroimmune Interactions in the Early Postpartum Period Influence Risk of Postpartum Depression" (2015). College of Nursing Faculty Research and Publications. 373.

https://epublications.marquette.edu/nursing_fac/373 
Authors

Elizabeth J. Corwin, Kathleen Pajer, Sudeshna Paul, Nancy Lowe, Mary Weber, and Donna O. McCarthy

This article is available at e-Publications@Marquette: https://epublications.marquette.edu/nursing_fac/373 


\title{
Bidirectional Psychoneuroimmune Interactions in the Early Postpartum Period Influence Risk of Postpartum Depression
}

\author{
Elizabeth J. Corwin \\ School of Nursing, Emory University, \\ Atlanta, GA \\ Kathleen Pajer \\ School of Medicine, University of Ottawa Faculty of Medicine, \\ Ottawa, Canada \\ Sudeshna Paul \\ School of Nursing, Emory University, \\ Atlanta, $G A$ \\ Nancy Lowe \\ College of Nursing, University of Colorado, \\ Aurora, CO \\ Mary Weber \\ College of Nursing, University of Colorado, \\ Aurora, CO \\ Donna O. McCarthy \\ College of Nursing, Marquette University, \\ Milwaukee, WI
}

Brain, Behavior, and Immunity, Vol 49 (October 2015): pg. 86-93. DOI. This article is (C) Elsevier and permission has been granted for this version to appear in e-Publications@Marquette. Elsevier does not grant permission for this article to be further copied/distributed or hosted elsewhere without the express permission from Elsevier. 
NOT THE PUBLISHED VERSION; this is the author's final, peer-reviewed manuscript. The published version may be accessed by following the link in the citation at the bottom of the page.

\begin{abstract}
More than 500,000 U.S. women develop postpartum depression (PPD) annually. Although psychosocial risks are known, the underlying biology remains unclear. Dysregulation of the immune inflammatory response and the hypothalamic-pituitary-adrenal (HPA) axis are associated with depression in other populations. While significant research on the contribution of these systems to the development of PPD has been conducted, results have been inconclusive. This is partly because few studies have focused on whether disruption in the bidirectional and dynamic interaction between the inflammatory response and the HPA axis together influence PPD. In this study, we tested the hypothesis that disruption in the inflammatory-HPA axis bidirectional relationship would increase the risk of PPD. Plasma pro- and anti-inflammatory cytokines were measured in women during the 3rd trimester of pregnancy and on Days 7 and 14, and Months 1, 2, 3, and 6 after childbirth. Saliva was collected 5 times the day preceding blood draws for determination of cortisol area under the curve (AUC) and depressive symptoms were measured using the Edinburgh Postpartum Depression Survey (EPDS). Of the 152 women who completed the EPDS, $18 \%$ were depressed according to EDPS criteria within the 6 months postpartum. Cortisol AUC was higher in symptomatic women on Day $14(p=.017)$. To consider the combined effects of cytokines and cortisol on predicting symptoms of PPD, a multiple logistic regression model was developed that included predictors identified in bivariate analyses to have an effect on depressive symptoms. Results indicated that family history of depression, day 14 cortisol AUC, and the day 14 IL8/IL10 ratio were significant predictors of PPD symptoms. One unit increase each in the IL8/IL10 ratio and cortisol AUC resulted in $1.50(p=0.06)$ and $2.16(p=0.02)$ fold increases respectively in the development of PPD. Overall, this model correctly classified $84.2 \%$ of individuals in their respective groups. Findings suggest that variability in the complex interaction between the inflammatory response and the HPA axis influence the risk of PPD.
\end{abstract}

Keywords: Postpartum depression, Inflammation, Cytokines, Cortisol, Cytokine-cortisol feedback circuit, Psychoneuroimmune

\title{
1. Introduction
}

Postpartum depression (PPD) is a major mood disorder (Association, 2013), affecting between $12 \%$ and $20 \%$ of new mothers (Gavin et al., 2005 and Wisner et al., 2010). PPD is characterized by persistent fatigue, sadness, and anxiety (Beck, 2006, Corwin et al., 2005 and Hay et al., 2008) and carries significant and lifelong health consequences for women and their infants (Field, 2010). These consequences may be intergenerational, as infants born to mothers with PPD grow up to be at an increased risk of developing a mood disorder themselves (Hay et al., 2008 and Pearson et al., 2013). Although psychosocial risk factors for PPD have long been considered,

Brain, Behavior, and Immunity, Vol 49 (October 2015): pg. 86-93. DOI. This article is (c) Elsevier and permission has been granted for this version to appear in e-Publications@Marquette. Elsevier does not grant permission for this article to be further copied/distributed or hosted elsewhere without the express permission from Elsevier. 
a growing appreciation of the mind-body connection in health and disease has led to an increased focus on biological risk factors that may underlie or contribute to the disorder. Two biological systems that have come under investigation as potential contributors to PPD are the immune-inflammatory response (Anderson and Maes, 2013, Boufidou et al., 2009, Corwin et al., 2008, Groer and Morgan, 2007, Maes et al., 2000, Okun et al., 2011 and Osborne and Monk, 2013) and the hypothalamic-pituitary-adrenal (HPA) axis (Glynn et al., 2013, O'Keane et al., 2011 and Okun et al., 2011). Both undergo significant changes during pregnancy (Kalantaridou et al., 2010, Mastorakos and Ilias, 2003 and Mor and Cardenas, 2010) and both remain in flux during the early postpartum period (Christian and Porter, 2014, Hebisch et al., 2004 and Mastorakos and Ilias, 2003).

While not an immunosuppressive state (Mor and Cardenas, 2010), for most of pregnancy there is a shift away from a proinflammatory and toward an anti-inflammatory milieu in the mother, protecting the fetus from rejection (Aagaard-Tillery et al., 2006). However, by the end of the 3rd trimester, a pro-inflammatory milieu again emerges (Maes et al., 2000 and Mor and Cardenas, 2010), playing an important role in the onset of parturition (Christiaens et al., 2008). This pro-inflammatory response accelerates during labor, as most women experience some degree of pain, anxiety, stress, and fatigue during that time, each of which serves as a stimulus for the secretion of pro-inflammatory cytokines (Steptoe et al., 2007 and Watkins et al., 1999). The inflammatory response continues into the postpartum period as both pro- and anti-inflammatory mediators drive perineal healing and uterine involution as well as mammary involution in women who chose to bottle feed (Chapwanya et al., 2012, Hojilla et al., 2011, Nilsen-Hamilton et al., 2003 and Salamonsen, 2003). Given the association between inflammation and depression in non-pregnant, non-postpartum populations (Dantzer and Kelley, 2007 and Raison and Miller, 2013), more than a dozen research studies over the past two decades have considered exaggerated postpartum inflammation as a risk factor for PPD. A recent literature review, however, concluded that findings are inconsistent and do not allow for conclusions or generalizations to be made (Osborne and Monk, 2013). Limitations of prior studies include small sample sizes, inclusion of women with birth complications, limited reliability or validity of measures used to evaluate depression,

Brain, Behavior, and Immunity, Vol 49 (October 2015): pg. 86-93. DOI. This article is (C) Elsevier and permission has been granted for this version to appear in e-Publications@Marquette. Elsevier does not grant permission for this article to be further copied/distributed or hosted elsewhere without the express permission from Elsevier. 
and samples collected at a single time, or at inconsistent times, after delivery. In addition, very few studies have addressed the biological complexity of the psychoneuroimmune (PNI) response, specifically, the bidirectional and dynamic interaction between the inflammatory response and the HPA axis.

Like the immune system, the HPA axis is altered during pregnancy; by the second trimester maternal levels of serum cortisol are nearly double compared to levels seen in the non-pregnant state (Mastorakos and Ilias, 2003). Key to this scenario is the increased production of corticotropin-releasing hormone $(\mathrm{CRH})$ by the placenta and fetal membranes as pregnancy advances; the resultant increase in cortisol production from these sources is resistant to negative feedback, although suppression of maternal hypothalamic $\mathrm{CRH}$ in response to the high levels of circulating cortisol is intact (Kalantaridou et al., 2010). With delivery of the infant and expulsion of the placenta, maternal cortisol levels fall significantly and quickly, to within the upper normal range (Chrousos et al., 1998). Maternal postpartum CRH suppression, however, has been hypothesized to continue for a variable period of time (Kalantaridou et al., 2010, Mastorakos and Ilias, 2003 and Vitoratos et al., 2006). A growing body of evidence suggests that the abrupt fall in cortisol levels and postpartum HPA axis suppression contribute to postpartum mood disorders (Bloch et al., 2005, Chrousos et al., 1998, Glynn et al., 2013, Kalantaridou et al., 2010, O'Keane et al., 2011 and Yim et al., 2009). Hyper- and hyposecretion of cortisol, and $\mathrm{CRH}$ deficiency have been linked to depression in non-pregnant and non-postpartum individuals as well (Charmandari et al., 2005, Chrousos, 1995 and Tsigos and Chrousos, 2002).

In addition to their individual effects, the pro-inflammatory response and the HPA axis exhibit significant bidirectional interactions via the well-documented cytokine-glucocorticoid feedback circuit (Besedovsky and del Rey, 1996, Elenkov, 2008 and Elenkov et al., 2005). In this circuit, an infectious or potentially injurious stressor increases production of pro-inflammatory cytokines, which in turn activate the HPA axis, increasing cortisol secretion. Rising cortisol levels then bind to glucocorticoid receptors, including white blood cell glucocorticoid receptors (Pace and Miller, 2009), ultimately turning off further transcription of pro-inflammatory cytokines such as interleukin-

Brain, Behavior, and Immunity, Vol 49 (October 2015): pg. 86-93. DOI. This article is (C) Elsevier and permission has been granted for this version to appear in e-Publications@Marquette. Elsevier does not grant permission for this article to be further copied/distributed or hosted elsewhere without the express permission from Elsevier. 
10 (IL-10). The net effect of this feedback circuit is to alert the central nervous system to the risk of an infectious or injurious stressor, while at the same time limiting a potentially damaging or prolonged proinflammatory response and constraining further cortisol secretion. If this circuit is disrupted, the ability of cortisol to limit inflammation may be lost (Miller et al., 1999, Miller et al., 2002, Miller et al., 2008, Miller et al., 2009 and Pace et al., 2012), leading to dysregulation of both cytokine production and cortisol secretion (Corwin et al., 2013). Nearly two decades ago, Chrousos and Tsigos suggested that disruption in the HPA axis-immune system bidirectional relationship could increase susceptibility to PPD (Chrousos, 1995 and Tsigos and Chrousos, 2002). To our knowledge, this hypothesis has not yet been tested.

\subsection{Research question}

The inflammatory immune system and the HPA axis function in a complex, inter-dependent manner over time to maintain baseline and stress-related homeostasis. Abnormal inflammation or dysregulation of the HPA axis has the potential to disrupt the relationship, carrying adverse consequences for mental and physical health. In light of the significant inflammatory and HPA axis changes following labor and delivery, and the known associations between depression, inflammation, and abnormal HPA axis activity in other populations (Anisman and Merali, 2003 and Raison et al., 2006), we tested the hypothesis that dysregulation in the bidirectional relationship between inflammation and the HPA axis early in the postpartum period would be associated with an increased risk of PPD in otherwise healthy women.

\section{Materials \& methods}

\subsection{Procedure}

Procedures were described in detail in a previous report identifying a pattern of glucocorticoid resistance in the 3rd trimester of pregnancy in the minority and low-income women enrolled in this study (Corwin et al., 2013). Briefly, women who responded to ads placed in community and clinic sites were recruited in their 2nd or early 3rd trimester of pregnancy. Following a screening interview,

Brain, Behavior, and Immunity, Vol 49 (October 2015): pg. 86-93. DOI. This article is (C) Elsevier and permission has been granted for this version to appear in e-Publications@Marquette. Elsevier does not grant permission for this article to be further copied/distributed or hosted elsewhere without the express permission from Elsevier. 
those meeting inclusion criteria were visited at home by a registered nurse a total of 7 times for data collection; once between 32 and 36 weeks of pregnancy and again at weeks one and two, and months $1,2,3$, and 6 after delivery. At the prenatal home visit, participants reviewed with the nurse the study protocol and provided informed consent for their participation. Participants next completed a demographic questionnaire providing information on age, marital status, race/ethnicity, personal and family history of depression, and whether or not they received government assistance through the Women, Infants, and Children (WIC) assistance program. Self-report of height, and pre-pregnancy weight was used for determination of pre-pregnancy body mass index (BMI). At this visit and at all subsequent home visits, women also completed questionnaires on current health status and on the presence of depressive symptoms via completion of the Edinburgh Postnatal Depression Scale (EPDS) (Cox et al., 1987) and perceived stress. Any subject scoring high $(\geqslant 10)$ on the EPDS or answered positively on the self-harm question were interviewed by the nurse and the psychiatric provider for any needed referrals or immediate intervention.

After completing all self-report tools, blood was drawn from the antecubital vein into EDTA-containing tubes for later measurement of plasma pro-inflammatory cytokines released as part of the innate immune response and implicated in depression (Anisman and Merali, 2003 and Raison et al., 2006), including interleukin-6 (IL-6), interleukin-1-beta (IL-1 $\beta$ ), tumor necrosis factor-alpha (TNF-a), interleukin-8 (IL-8) and interferon-gamma (IFN-Y). Because the inflammatory response is regulated by the concurrent production of anti-inflammatory cytokines, (Petrovsky, 2001), we also measured the anti-inflammatory cytokine interleukin-10 (IL-10). In addition, during the day prior to each home visit, subjects collected a saliva sample upon awakening, 30-min after awakening, at 11:00 AM, 4:00 PM, and 8:00 PM. Home visits lasted approximately 30-min. At the end of each home visit, women were compensated for participating and the next home visit was arranged. All methods employed to improve the accuracy and compliance of the home saliva collections (e.g., phone calls prior to each sample collection, the use of Medication Event Monitoring System [MEMS $®$ ], Aprex Corp., Fremont, Calif.)] caps, and reimbursement for accurate collections have been described previously (Corwin et al., 2013).

Brain, Behavior, and Immunity, Vol 49 (October 2015): pg. 86-93. DOI. This article is (C) Elsevier and permission has been granted for this version to appear in e-Publications@Marquette. Elsevier does not grant permission for this article to be further copied/distributed or hosted elsewhere without the express permission from Elsevier. 
NOT THE PUBLISHED VERSION; this is the author's final, peer-reviewed manuscript. The published version may be accessed by following the link in the citation at the bottom of the page.

\subsection{Inclusion/exclusion criteria}

Prenatal inclusion criteria were that all women were between 18 and 40 years of age, less than 36-weeks pregnant, non-smokers, and anticipating the vaginal birth of a singleton infant. Additionally, women were required to be without pregnancy restrictions, free of any known chronic illness, and, with the exception of prenatal vitamins, not taking any over-the-counter or prescribed medications or herbs including anti-inflammatory or anti-depressant agents. Postnatal criteria for continued inclusion were that women delivered a live infant via a vaginal birth, without experiencing hemorrhage or transfusion, and that both mother and infant left the hospital together within 72-h of delivery. These inclusion/exclusion criteria were established to reduce to the extent possible prenatal or postnatal conditions that might themselves be associated with inflammation and/or depressed mood. Subjects also were required to be without symptoms of infection at the time of each home visit (or the visit was rescheduled) and to live within a 20 miles of the laboratory, to minimize the time biological samples were in transport. Postpartum visits at 1- and 2-weeks were scheduled $\pm 48-\mathrm{h}$, while the 1-, 2-, 3-, and 6-month visits were scheduled \pm 1 week.

\subsection{Measures}

The 10-item EPDS was used for self-report of depressive symptoms (Cox et al., 1987). It is an effective and easy to administer screening tool that has been validated for both antepartum and postpartum use. Answers to questions such as "I have looked forward with enjoyment to things" are scored from 0 ("As much as I ever did") to 4 ("Hardly at all"). After completion, a woman's score is summed to provide information on the likelihood of clinical depression. Validation of the EPDS against a diagnostic clinical interview identified a specificity of $78 \%$, a sensitivity of $86 \%$, and a positive predictive value of $73 \%$ for women scoring $>10$. Although a cut-point of $>9$ on the EPDS during the first weeks postpartum has more recently been shown to increase the specificity of the tool (Chaudron et al., 2010 and Teissedre and Chabrol, 2004), we retained the traditional cut-point since we were following participants through 6-months postpartum where the cut-point recommendations are higher.

Brain, Behavior, and Immunity, Vol 49 (October 2015): pg. 86-93. DOI. This article is (C) Elsevier and permission has been granted for this version to appear in e-Publications@Marquette. Elsevier does not grant permission for this article to be further copied/distributed or hosted elsewhere without the express permission from Elsevier. 
The 14-item Perceived Stress Scale (PSS) was used to provide information on participants' perception of stress (Cohen et al., 1983). The responses are based on a Likert-scale from 0 to 4, or from "never" to "very often". Each question asks the individual how she has been feeling during the past month. The final score is a simple sum of each item response, with some items reverse coded. In Cohen's original report, internal consistency reliability was high (Cronbach's alpha coefficients ranged from 0.84 to 0.86 ) as was test-retest correlation $(0.85)$. Evidence for concurrent and predictive validity was significant at $p<0.05(r=0.49)$. Scores on the PSS have been shown to correlate with measures of HPA axis function during pregnancy and the post-partum period (Ruiz et al., 2003) and with depressive symptoms (Shelton et al., 2014).

\subsection{Biomarkers}

Upon reaching the laboratory, blood samples were centrifuged at $4{ }^{\circ} \mathrm{C}$ for $8 \mathrm{~min}$ at $2000 \mathrm{rpm}$. Plasma aliquots were placed into $1.5 \mathrm{cc}$ polypropylene microtubes and stored in the study lab at $-80{ }^{\circ} \mathrm{C}$, until assayed using a Human Pro-inflammatory Ultra-Sensitive assay and quantitative multiplex array technology (Meso Scale Discovery, Gaithersburg, Maryland). All samples were measured in duplicate. Intra-assay coefficient of variation was $<5 \%$ and inter-assay coefficient of variation was $<10 \%$. Cytokine concentrations are reported individually and, since reciprocal interactions between proand anti-inflammatory cytokines finely tune the immune response (Petrovsky and Harrison, 1997) and may best predict the risk for depression in some clinical populations (Guilbaud et al., 2009 and Taraz et al., 2012), the ratio of each pro-inflammatory cytokine to anti-inflammatory cytokine (e.g., IL-6/IL-10) was measured as well and considered in analyses.

Saliva samples were centrifuged at $4{ }^{\circ} \mathrm{C}$ for $3 \mathrm{~min}$ at $2000 \mathrm{rpm}$ after which they were aliquoted into $1.5 \mathrm{cc}$ polypropylene microtubes for storage at $-80{ }^{\circ} \mathrm{C}$ until assayed using an expanded range high sensitivity EIA kit (No. 1-3002/1-3012, Salimetrics, State College, PA). Intra-assay coefficient of variation was $4.3 \%$ and inter-assay coefficient of variation was $5.2 \%$. The area under the curve (AUC) was determined with respect to ground (Pruessner et al., 2003), and

Brain, Behavior, and Immunity, Vol 49 (October 2015): pg. 86-93. DOI. This article is (C) Elsevier and permission has been granted for this version to appear in e-Publications@Marquette. Elsevier does not grant permission for this article to be further copied/distributed or hosted elsewhere without the express permission from Elsevier. 
NOT THE PUBLISHED VERSION; this is the author's final, peer-reviewed manuscript. The published version may be accessed by following the link in the citation at the bottom of the page.

indicates the amount of cortisol secreted over the designated time ( $\mu \mathrm{g} / \mathrm{dL} /$ hour).

\subsection{Statistical analysis}

For descriptive analysis of the study sample, mean (standard deviations) and percentages were computed for continuous and categorical demographics (such as age, race, marital status and indicator of socioeconomic status) and baseline psychosocial variables (prior history of depression, family history of depression, prenatal total EPDS).

To compare differences in cytokine levels and their pro- to antiinflammatory ratios between groups of women who were symptomatic of PPD ( $>10$ on the EPDS) reported anytime up to 6 months postpartum versus those not, independent sample Student $t$-tests were performed. Because the cytokine and cortisol data were skewed, natural log transformations were conducted prior to all analyses; tables and graphs, however, report absolute levels. Temporal differences in cytokine ratios (IL1ß/IL10, IL6/IL10, IL8/IL10, IFNy/IL10, TNFa/IL10) and cortisol AUC in women non-symptomatic or symptomatic of PPD were assessed at the prenatal visit and days 7 and 14, and months $1,2,3$ and 6 postpartum using repeated measures analysis. Graphical analysis was used to detect patterns in cytokine ratios and cortisol AUC and their interactions and identify time points where these were significantly different between women non-symptomatic and symptomatic of depressive symptoms. Consecutively, at time points that indicated significant differences, joint cytokine-cortisol relationship trends were investigated for groups- with and without symptoms of PPD by using multiple linear regression methods and significant differences in trends were graphically illustrated.

Because the outcome (whether symptomatic of PPD) is binary, bivariate and multivariate logistic regressions were performed to examine the individual (unadjusted) and joint (adjusted for other predictors) effects of pro- to anti-inflammatory cytokine ratios, and cortisol on the risk of PPD in postpartum women. Particularly, the proto anti-inflammatory cytokine ratios and cortisol AUCs at days 7 and 14 were evaluated to capture the dynamic, early postpartum milieu.

Brain, Behavior, and Immunity, Vol 49 (October 2015): pg. 86-93. DOI. This article is (c) Elsevier and permission has been granted for this version to appear in e-Publications@Marquette. Elsevier does not grant permission for this article to be further copied/distributed or hosted elsewhere without the express permission from Elsevier. 
The multiple logistic regression model adjusted for baseline demographics and psychosocial characteristics that were significantly different across the two groups. Cortisol, cytokines, and pro- to antiinflammatory cytokine ratios that were identified in the analyses to have a theoretical or statistically significant effect on the occurrence of depressive symptoms in postpartum women were included.

Statistical analysis was performed using SAS (version 9.2; SAS Institute, Cary, NC) and SPSS 20. All statistical tests were two-sided and a $p$ value of $<0.05$ was considered statistically significant.

\section{Results}

\subsection{Demographic data}

Two-hundred and one women were enrolled in the study during their 3rd trimester of pregnancy. Of this number, 49 (24\%) were lost or discontinued from further participation either prior to or immediately following delivery due to the following reasons: lack of interest or personal reasons $(n=8)$; having moved out of the area $(n=2)$; ill infant unable to leave the hospital within 72-h of birth $(n=5)$; stillbirth $(n=1)$; development of maternal prenatal health complication (hypertension, $n=2$ ); or labor and delivery complication (cesarean birth, $n=26$ or maternal hemorrhage/transfusion, $n=5$ ). This resulted in 152 women who continued in the study postpartum. Of this group, $18 \%(n=27)$ scored symptomatic of depression (EPDS $\geqslant 10$ ) during the 6 -months postpartum. Demographic and psychosocial data for the entire group, and for those who did or did not score symptomatic of depression, are shown in Table 1. Among baseline demographic characteristics, self-report of prior history of depression, prenatal EPDS score, and family history of depression ( $p=0.020, p=0.033$ and $p=0.008$, respectively) were significantly different in women who scored symptomatic of depression within 6months compared to those who did not and thus these variables were controlled for in the final predictive model for PPD symptoms. PSS scores were also significantly different between groups at every time point; however, because they were also highly and positively correlated $(p<0.0001)$ with our primary outcome variable (EPDS

Brain, Behavior, and Immunity, Vol 49 (October 2015): pg. 86-93. DOI. This article is (C) Elsevier and permission has been granted for this version to appear in e-Publications@Marquette. Elsevier does not grant permission for this article to be further copied/distributed or hosted elsewhere without the express permission from Elsevier. 
scores) across and between all-time points, we did not include PSS in the final model.

Table 1. Demographic and clinical characteristics of women who were not or were symptomatic of PPD ( $\geqslant 10$ on EPDS) at any time during the first 6months postpartum (mean \pm SD).

\begin{tabular}{|c|c|c|c|}
\hline & Symptomatic of & PD in 1st 6 months & \\
\hline & No $(n=125)$ & Yes $(n=27)$ & \\
\hline Age & $29.01(5.44)$ & $28.70(4.29)$ & 0.79 \\
\hline BMI & $23.72(4.21)$ & $24.48(4.58)$ & 0.40 \\
\hline Marital status: married & $80.0 \%$ & $85.2 \%$ & 0.51 \\
\hline Race: caucasian & $76.0 \%$ & $85.2 \%$ & 0.30 \\
\hline Higher Income & $72.6 \%$ & $85.2 \%$ & 0.17 \\
\hline Personal history of depression & $18.4 \%$ & $37.0 \%$ & 0.03 \\
\hline Family history of depression & $35.2 \%$ & $63.0 \%$ & 0.01 \\
\hline Prenatal EPDS & $4.08(3.35)$ & $6.64(4.60)$ & 0.00 \\
\hline
\end{tabular}

\subsection{Inflammatory markers}

As shown in Table 2, levels of all cytokines were significantly increased after delivery compared to prenatal levels, beginning by 1week postpartum and continuing, some throughout the study duration. When comparing women who had a score indicating PPD to those who were not depressed at any time, cytokine analyses at each time point (days 7, 14, months 1, 2, 3 and 6) indicated that only TNFa levels were significantly different between groups, with lower TNFa levels $(p<0.05)$ at all time points in women symptomatic of PPD (Table 3$)$. There were no differences in any other cytokine or in the ratios of any pro- to anti-inflammatory cytokine among women who did or did not score symptomatic of depression, although day $14 \mathrm{IL}-8 / \mathrm{IL}-10$ ratio was marginally higher among those symptomatic of PPD compared to those non-symptomatic $(p=0.066)$. Repeated measures analysis indicated that over time, the group symptomatic of depression had lower TNF-a ( $p=0.009)$, confirming findings from the cross-sectional analysis. Similar trends in repeated measures analyses existed for all other cytokines and pro- to anti-inflammatory cytokine ratios, i.e., lower individual cytokine levels but higher pro- to anti-inflammatory ratios in women symptomatic of PPD.

Brain, Behavior, and Immunity, Vol 49 (October 2015): pg. 86-93. DOI. This article is (C) Elsevier and permission has been granted for this version to appear in e-Publications@Marquette. Elsevier does not grant permission for this article to be further copied/distributed or hosted elsewhere without the express permission from Elsevier. 
Table 2. Pro- and anti-inflammatory cytokine $(\mathrm{pg} / \mathrm{ml})$ levels (mean $+\mathrm{SE}$ ) and cortisol area under the curve (AUC) during the prenatal period through 6months postpartum.

Prenatal Day 7 Day 14 Month 1 Month 2 Month 3 Month 6

IL-6

$\begin{array}{lllllll}1.86 & 3.08^{* *} & 1.85 & 1.93 & 1.82 & 2.06 * & 1.73 *\end{array}$

$\begin{array}{lllllll}( \pm .20) & ( \pm .28) & ( \pm .19) & ( \pm .21) & ( \pm .28) & ( \pm .49) & ( \pm .18)\end{array}$

IFNY

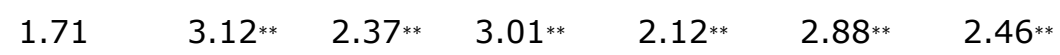

$\begin{array}{lllllll}( \pm .16) & ( \pm .49) & ( \pm .27) & ( \pm .38) & ( \pm .20) & ( \pm .58) & ( \pm .36)\end{array}$

TNFa

$\begin{array}{lllllll}5.49 & 6.27^{* *} & 6.22^{* *} & 6.84^{* *} & 6.30^{* *} & 6.85^{* *} & 6.95^{*}\end{array}$

$\begin{array}{lllllll}( \pm .29) & ( \pm .37) & ( \pm .34) & ( \pm .37) & ( \pm .35) & ( \pm .42) & ( \pm .52)\end{array}$

IL-1 $\beta$

$\begin{array}{lllllll}0.52 & 1.06^{* *} & 0.76^{* *} & 1.38^{* *} & 0.90^{*} & 0.78^{*} & 0.81^{*}\end{array}$

$\begin{array}{lllllll}( \pm .07) \quad( \pm .39) & ( \pm .13) & ( \pm .49) & ( \pm .21) & ( \pm .14) & ( \pm .18)\end{array}$

IL-10

$\begin{array}{lllllll}7.32 & 9.72 * * & 10.19 * & 10.50 & 11.70 & 10.87 & 11.81\end{array}$

$\begin{array}{lllllll}( \pm 1.95) & ( \pm 2.96) & ( \pm 4.13) & ( \pm 3.21) & ( \pm 4.73) & ( \pm 3.66) & ( \pm 3.87)\end{array}$

IL-8

$\begin{array}{lllllll}4.10 & 6.02^{* *} & 6.52^{* *} & 5.99^{* *} & 5.94^{* *} & 5.69^{* *} & 5.66^{* *}\end{array}$

$\begin{array}{lllllll}( \pm .37) & ( \pm .22) & ( \pm .75) & ( \pm .79) & ( \pm 1.08) & ( \pm .76) & ( \pm 1.02)\end{array}$

Cortisol AUC $\begin{array}{lllllll}3.29 & 2.35^{* *} & 1.96^{* *} & 1.68^{* *} & 1.72^{* *} & 1.60^{* *} & 1.64^{* *} \\ ( \pm .09) & ( \pm .08) & ( \pm .07) & ( \pm .06) & ( \pm .14) & ( \pm .05) & ( \pm .09)\end{array}$

For comparisons against prenatal levels: ${ }^{*}$ indicates $p \leqslant 0.05,{ }^{* *}$ indicates $p \leqslant 0.005$.

Table 3. Pro- and anti-inflammatory cytokines $(\mathrm{pg} / \mathrm{ml})$ from day 7 through 6months postpartum in women who did or did not score symptomatic of PPD $\left({ }^{*} p<0.05\right)$.

\begin{tabular}{|c|c|c|c|c|c|}
\hline Day 7 & Day 14 & Month 1 & Month 2 & Month 3 & Month 6 \\
\hline \multicolumn{6}{|l|}{$I L-6$} \\
\hline EPDS $<103.13 \pm .33$ & $1.93 \pm .23$ & $2.03 \pm .25$ & $1.91 \pm .34$ & $2.21 \pm .60$ & $1.82 \pm .22$ \\
\hline EPDS > $102.45 \pm .26$ & $1.51 \pm .20$ & $1.47 \pm .19$ & $1.44 \pm .21$ & $1.12 \pm .17$ & $1.35 \pm .18$ \\
\hline \multicolumn{6}{|l|}{$I F N_{Y}$} \\
\hline EPDS $<103.38 \pm .60$ & $2.49 \pm .33$ & $3.21 \pm .46$ & $2.08 \pm .20$ & $3.01 \pm 70$ & $2.61 \pm .44$ \\
\hline EPDS > $102.00 \pm .36$ & $1.78 \pm .24$ & $1.83 \pm .29$ & $2.30 \pm .64$ & $1.86 \pm .36$ & $1.87 \pm .31$ \\
\hline \multicolumn{6}{|l|}{$T N F-a$} \\
\hline EPDS $<106.65 \pm .44^{*}$ & $6.57 \pm .40^{*}$ & * $7.22 \pm .44 *$ & $6.65 \pm .41^{*}$ & $7.31 \pm .49^{*}$ & $7.50 \pm .62 *$ \\
\hline EPDS > $104.62 \pm .50$ & $4.68 \pm .45$ & $5.10 \pm .53$ & $4.81 \pm .53$ & $4.54 \pm .47$ & $4.64 \pm .53$ \\
\hline
\end{tabular}

Brain, Behavior, and Immunity, Vol 49 (October 2015): pg. 86-93. DOI. This article is (C) Elsevier and permission has been granted for this version to appear in e-Publications@Marquette. Elsevier does not grant permission for this article to be further copied/distributed or hosted elsewhere without the express permission from Elsevier. 
NOT THE PUBLISHED VERSION; this is the author's final, peer-reviewed manuscript. The published version may be accessed by following the link in the citation at the bottom of the page.

\section{Day 7 Day 14 Month 1 Month 2 Month 3 Month 6}

EPDS $<101.15 \pm .48 \quad 0.83 \pm .16 \quad 1.38 \pm .58 \quad 0.99 \pm .25 \quad 0.79 \pm .16 \quad 0.89 \pm .23$

EPDS > $100.68 \pm .290 .44 \pm .07 \quad 1.31 \pm .590 .39 \pm .08 \quad 0.47 \pm .13 \quad 0.46 \pm .16$

$I L-10$

EPDS < $1011.2 \pm .3 .711 .8 \pm 5.112 .2 \pm 3.913 .6 \pm 5.8 \quad 12.6 \pm 4.513 .9 \pm 4.9$

EPDS > $103.8 \pm .0 .8 \quad 3.6 \pm 0.7 \quad 3.4 \pm 0.6 \quad 3.8 \pm 1.2 \quad 3.0 \pm 0.5 \quad 3.3 \pm 0.7$

$I L-8$

EPDS $<106.05 \pm .266 .69 \pm .936 .34 \pm .976 .24 \pm 1.335 .91 \pm .945 .96 \pm 1.26$

EPDS > $106.09 \pm .356 .07 \pm .424 .61 \pm .28 \quad 4.75 \pm 0.264 .61 \pm .324 .62 \pm 0.44$

\subsection{Cortisol levels}

Across the days of saliva collections, only during the early postpartum period, on day 14, were cortisol levels higher in women with PPD ( $p=0.015)$ (Table 4$)$. Cortisol AUC at day 14 was a significant predictor of PPD symptoms and the odds of having PPD symptoms increased by $82 \%$ with a one unit change in Cortisol AUC (OR: $1.82, p=0.025$ ).

Table 4. Salivary cortisol Area Under the Curve (AUC) in women who were not or were symptomatic of depression (EPDS $\geqslant 10$ ) at any time through 6months postpartum (mean $\pm \mathrm{SE}$ ).

\begin{tabular}{|c|c|c|c|}
\hline \multirow{2}{*}{ Time } & \multicolumn{2}{|c|}{ Symptomatic of PPD in 1st 6 months } & \multirow{2}{*}{$p$-Value } \\
\hline & No $(N=125)$ & Yes $(N=27)$ & \\
\hline Prenatal & $3.25(0.09)$ & $3.65(0.27)$ & NS \\
\hline Day 7 & $2.33(0.09)$ & $2.51(0.22)$ & NS \\
\hline Day 14 & $1.89(0.07)$ & $2.36(0.20)$ & $0.015^{*}$ \\
\hline Month 1 & $1.65(0.06)$ & $1.81(0.20)$ & NS \\
\hline Month 2 & $1.58(0.05)$ & $2.45(0.84)$ & NS \\
\hline Month 3 & $1.61(0.06)$ & $1.56(0.09)$ & NS \\
\hline Month 6 & $1.66(0.12)$ & $1.55(0.12)$ & NS \\
\hline
\end{tabular}

\subsection{Cytokine-cortisol interactions}

The cytokines IL-6, IL-10, IL-8, and IFNy tended to show substantially different relationship patterns with cortisol AUC in women who were symptomatic of depression compared to those nonsymptomatic, peaking at 2-weeks postpartum; these patterns were significantly different for IL-6 and IL-10 (Fig. 1). Specifically, in the

Brain, Behavior, and Immunity, Vol 49 (October 2015): pg. 86-93. DOI. This article is (C) Elsevier and permission has been granted for this version to appear in e-Publications@Marquette. Elsevier does not grant permission for this article to be further copied/distributed or hosted elsewhere without the express permission from Elsevier. 
depressed women, cortisol AUC increased with increasing levels of these cytokines; this was not true in the women without depression. Instead, in the non-depressed women, there was no relationship between any measured cytokine and cortisol AUC. These differences in patterns between the two groups were more profound in the first weeks after childbirth; any difference between groups disappeared gradually after month 1 . Lastly, because scrutiny of the cytokine data identified some substantial outliers, we conducted a secondary analysis of the data, deleting outliers as defined by inter-quartile range (IQR) of cytokine \pm three standard deviations. Since this did not significantly impact our findings, and for the purpose of representing all data, Fig. 1 is inclusive of all subjects.

Fig. 1. Interactions between natural log-transformed cytokine and cortisol AUC in women who were and were not symptomatic of PPD at day 14. Relationship between cortisol AUC and IL- 6 and IL-10 were significantly different ( $p=0.007$ and $p=0.004$, respectively) for the two groups while they were not significantly different for IL-8 and IFN-Y $(p=0.187$ and $p=0.274$, respectively).
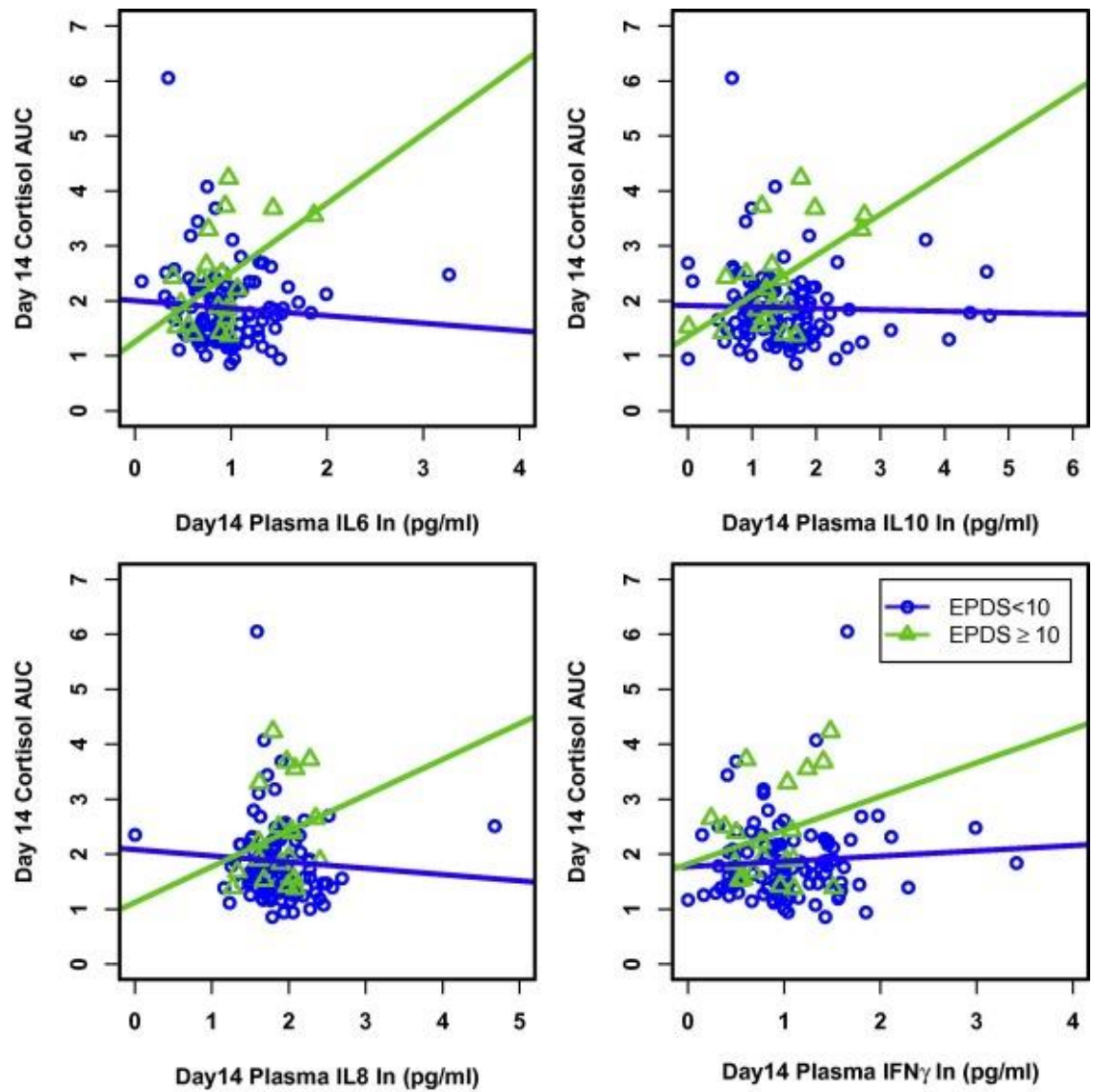

Brain, Behavior, and Immunity, Vol 49 (October 2015): pg. 86-93. DOI. This article is (C) Elsevier and permission has been granted for this version to appear in e-Publications@Marquette. Elsevier does not grant permission for this article to be further copied/distributed or hosted elsewhere without the express permission from Elsevier. 
To consider the combined effects of cytokines and cortisol on predicting symptoms of PPD, a multiple logistic regression model was developed that included predictors identified in bivariate analyses (e.g., day 14 cortisol AUC, TNF-a, IL-8/IL-10 ratio, IL-6 and IL-10). In addition, other baseline characteristics that were different across the two groups were included and backward elimination was used to identify the final model (Table 5). Neither baseline EPDS scores, personal history of depression, nor TNF-a, IL-6, IL-10 or their ratios (TNF-a/IL-10, IL6/IL10) were significant in predicting PPD symptoms in postpartum women and were discarded from the final model.

Table 5. Estimates of effects (odds ratios) from multiple logistic regression model for predicting PPD symptoms.

\begin{tabular}{|c|c|c|c|c|c|c|}
\hline \multirow{2}{*}{ Predictors } & \multirow{2}{*}{ B } & \multirow{2}{*}{ S.E. } & \multirow{2}{*}{ Sig. } & \multirow{2}{*}{$\operatorname{Exp}(B)$} & \multicolumn{2}{|c|}{ 95\% C.I. for EXP(B) } \\
\hline & & & & & Lower & Upper \\
\hline Depression_famhx(1) & -1.217 & 0.546 & .026 & .296 & .101 & .864 \\
\hline Day14_IL8_IL10_PCytokine_log & .406 & 0.216 & .060 & 1.50 & 0.984 & 2.292 \\
\hline Day14_AUC & 0.770 & 0.334 & .021 & 2.160 & 1.123 & 4.156 \\
\hline Constant & -2.867 & 0.782 & .000 & .057 & & \\
\hline
\end{tabular}

As shown in Table 5, the final multiple logistic regression model indicated that family history of depression, day 14 IL8/IL10 ratio and day 14 cortisol AUC were statistically significant predictors of PPD symptoms. Particularly, a unit increase in the IL8/IL10 ratio and a unit $(1 \mathrm{~h})$ increase in the cortisol AUC resulted in a $1.50(p=0.06)$ and $2.16(p=0.02)$ times increase in the likelihood of observing depressive symptoms in postpartum women respectively. In contrast, not having a prior family history of depression resulted in a $45.4 \%$ ( $p=0.03$ ) decrease in observing depressive symptoms. Overall, this model correctly classified $84.2 \%$ of the participants. Even without including a family history of depression, the model correctly classified $82.5 \%$ of individuals.

\section{Conclusions}

Although significant research has been conducted to identify and relieve psychosocial risk factors for PPD (Dennis and Dowswell, 2013), considering psychosocial risk factors alone continues to leave a large amount of variance in risk of PPD unexplained. A growing appreciation

Brain, Behavior, and Immunity, Vol 49 (October 2015): pg. 86-93. DOI. This article is (C) Elsevier and permission has been granted for this version to appear in e-Publications@Marquette. Elsevier does not grant permission for this article to be further copied/distributed or hosted elsewhere without the express permission from Elsevier. 
of the mind-body connection in health and disease has led to an increased focus on biological processes that may underlie or contribute to the disorder (Albacar et al., 2010, Binder et al., 2010, Bloch et al., 2000, Corwin et al., 2003, Costas et al., 2010, Figueira et al., 2010, Goshtasebi et al., 2013, Guintivano et al., 2013, Kimmel et al., 2013, Le Donne et al., 2012, Maes et al., 2002 and O'Keane et al., 2011). In the current study, our primary finding, that variability in the functioning of the bi-directional interactions between the immuneinflammatory response and the HPA axis within the first weeks after childbirth influences a woman's risk of PPD, further emphasizes the importance of an integrated PNI response in the postpartum mental health continuum.

Although our original hypothesis was that dysregulation of the cytokine/cortisol relationship postpartum would increase a woman's risk of PPD, our data suggest just the opposite: "dysregulation" after giving birth may protect women against depressed mood. This paradox of high cytokines and low cortisol provides additional support for the recognition of pregnancy and the postpartum as physiologically unique periods of life characterized by tightly regulated inflammatory states (Aagaard-Tillery et al., 2006 and Mor and Cardenas, 2010; Shelton et al., 2014).

The changes in cytokine and cortisol AUC levels after delivery compared to levels during the 3rd trimester of pregnancy (Table 2) highlight the significant activation of both arms of the immune response in the first days and weeks after childbirth. In nonpostpartum individuals, sudden increases in pro-inflammatory cytokines similar to those seen immediately after childbirth might be expected to increase cortisol secretion (Besedovsky and del Rey, 2006). However, our data suggest that in healthy women, this response is blunted or absent; thus although pro-inflammatory cytokines rise following labor and delivery, cortisol levels do not, reflecting postpartum HPA axis suppression continuing for at least the first 2-weeks after delivery. In contrast, for women who develop symptoms of PPD, the cytokine stimulation of cortisol secretion in the early postpartum is robust, and negatively impacts mood. We propose that these women experience an early postpartum return of hypothalamic responsiveness, as suggested by the significantly positive interactive effect between cytokines and cortisol in postpartum

Brain, Behavior, and Immunity, Vol 49 (October 2015): pg. 86-93. DOI. This article is (C) Elsevier and permission has been granted for this version to appear in e-Publications@Marquette. Elsevier does not grant permission for this article to be further copied/distributed or hosted elsewhere without the express permission from Elsevier. 
women who developed significant symptoms of PPD but not in women who did not (Fig. 1).

The data presented in Table 2, showing mean cytokine and cortisol AUC levels from the 3rd trimester of pregnancy through 6months postpartum are also notable in that they provide for the first time, a comprehensive view of PNI activity across approximately 8months during this critical pre- to post-natal period (32-36 weeks of pregnancy - 6 months postpartum). The significant changes in both the innate immune response and the HPA axis during pregnancy and the postpartum period highlight the uniqueness of these times in a woman's life (Aagaard-Tillery et al., 2006 and Mor and Cardenas, 2010). Further investigation of these cytokine profiles over time in a larger sample is warranted.

Although research supporting a direct, positive association between markers of inflammation and major depression has been identified in a variety of populations, evidence for this linkage in pregnant and postpartum women has been inconclusive (Osborne and Monk, 2013). In this study, we found that decreased levels of TNF-a were associated with symptoms of depression, although when considering the ratio of TNF-a/IL-10, this relationship was lost. Deceased TNF-a in the depressed women, might also reflect an intact cytokine-glucocorticoid feedback circuit in this population, where higher levels of cortisol limit further secretion of pro-inflammatory cytokines (Pace et al., 2012 and Yang and Glaser, 2002). The cytokine-glucocorticoid feedback circuit appears not to be active in women who do not develop symptoms of PPD, further suggesting that cytokine/cortisol "dysregulation" may be beneficial during this unique time.

The data presented in this also study may partially explain why previous studies of the relationship between cytokines and the development of PPD have been inconclusive, and why both hyper-and hypo-activity of the HPA axis have been linked with risk of PPD. First, our data suggest that cytokines and cortisol interact to influence mood, and that the timing and sequence of their interactions during the postpartum period is critical. In addition, considering the balance of pro- to anti-inflammatory cytokines, rather than just individual cytokines, appears necessary to uncover the full picture. While pro-

Brain, Behavior, and Immunity, Vol 49 (October 2015): pg. 86-93. DOI. This article is (C) Elsevier and permission has been granted for this version to appear in e-Publications@Marquette. Elsevier does not grant permission for this article to be further copied/distributed or hosted elsewhere without the express permission from Elsevier. 
inflammatory cytokines, such as TNF- $a$, IFN- $\gamma$, IL- $1 \beta$, and IL- 6 coordinate the non-specific (inflammatory) immune responses, antiinflammatory cytokines such as interleukin IL-10 not only provide negative feedback to limit inflammation, but also support development of a type 2, or specific immune response (Petrovsky and Harrison, 1997). The findings in this study emphasize the importance of the interplay between these two arms of the immune response to affect mood, and mirror findings from other studies emphasizing the importance of considering pro- to anti-inflammatory cytokine ratios when evaluating risks for depression (Bensimon et al., 2014 and Fredericks et al., 2010). And lastly, the variability in previously published findings on inflammation and PPD may be due as well to the timing of sample collections, the sources of sample, or the inclusion of women with confounding perinatal experiences such as surgical birth or transfusion, or co-morbidities known to affect the immune system or mood.

Limitations to this study include a relatively small number of participants and reliance on self-report of key variables including prepregnancy body weight and height, affective symptoms, and personal and family history of depression. The inclusion of self-report of personal and family history of depression may be especially problematic since we did not require that answering "yes" to either required that they be confirmed by a clinical diagnosis and/or treated medically, although some women might have interpreted the question that way. Likewise, requiring that all postpartum women must have had an uncomplicated, vaginal delivery of a healthy singleton infant, and that both mother and infant left the hospital together within 72-h of delivery, limits the generalizability of our findings. Lastly, this study utilized only indirect evidence of postpartum HPA axis responsiveness. Clearly, further investigation of the hypotheses tested in this study is needed in order to better understand the underlying mechanisms of PPD and to predict and prevent its occurrence in susceptible women.

In summary, to our knowledge, our study provides the first evidence that HPA axis responsiveness to inflammatory mediators in the early weeks after delivery significantly increases the risk of PPD. By simultaneously collecting and analyzing longitudinal data on cytokines and HPA activity we were able to detect an interaction between these two systems. It appears that variability in HPA axis

Brain, Behavior, and Immunity, Vol 49 (October 2015): pg. 86-93. DOI. This article is (C) Elsevier and permission has been granted for this version to appear in e-Publications@Marquette. Elsevier does not grant permission for this article to be further copied/distributed or hosted elsewhere without the express permission from Elsevier. 
responsiveness during the postpartum period may explain why some women develop depression when exposed to the inflammatory stimuli associated with the childbearing process while others do not.

\section{Acknowledgments}

This work was supported by NIH Grant 1R01NR011278 to EJC and KP.

\section{References}

Aagaard-Tillery et al., 2006.K.M. Aagaard-Tillery, R. Silver, J. Dalton.Immunology of normal pregnancy. Semin. Fetal Neonatal Med., 11 (2006), pp. 279-295

Albacar et al., 2010. G. Albacar, T. Sans, R. Martin-Santos, L. Garcia-Esteve, R. Guillamat, J. Sanjuan, F. Canellas, J.M. Carot, M. Gratacos, J. Bosch, et al. Thyroid function $48 \mathrm{~h}$ after delivery as a marker for subsequent postpartum depression. Psychoneuroendocrinology, 35 (2010), pp. 738-742

Anderson and Maes, 2013. G. Anderson, M. Maes. Postpartum depression: psychoneuroimmunological underpinnings and treatment.

Neuropsychiatry Dis. Treat., 9 (2013), pp. 277-286

Anisman and Merali, 2003. H. Anisman, Z. Merali. Cytokines, stress and depressive illness: brain-immune interactions. Ann. Med., 35 (2003), pp. $2-11$

Association, 2013. A.P. Association. Diagnostic and Statistical Manual of Mental Disorders. (fifth ed.) American Psychiatric Publishing, Arlington, VA (2013)

Beck, 2006. C.T. Beck. Postpartum depression: it isn't just the blues. Am. J. Nurs., 106 (2006), pp. 40-50 quiz 50-41

Bensimon et al., 2014. K. Bensimon, N. Herrmann, W. Swardfager, H. Yi, S.E. Black, F.Q. Gao, A. Snaiderman, K.L. Lanctot. Kynurenine and depressive symptoms in a poststroke population. Neuropsychiatry Dis. Treat., 10 (2014), pp. 1827-1835

Besedovsky and del Rey, 1996. H.O. Besedovsky, A. del Rey. Immune-neuroendocrine interactions: facts and hypotheses. Endocr. Rev., 17 (1996), pp. 64-102

Besedovsky and del Rey, 2006. H.O. Besedovsky, A. del Rey. Regulating inflammation by glucocorticoids. Nat. Immunol., 7 (2006), p. 537

Binder et al., 2010. E.B. Binder, U.J. Newport, E.B. Zach, A.K. Smith, T.C. Deveau, L.L. Altshuler, L.S. Cohen, Z.N. Stowe, J.F. Cubells. A serotonin transporter gene polymorphism predicts peripartum depressive symptoms in an at-risk psychiatric cohort. J. Psychiatr. Res., 44 (2010), pp. 640-646

Brain, Behavior, and Immunity, Vol 49 (October 2015): pg. 86-93. DOI. This article is (C) Elsevier and permission has been granted for this version to appear in e-Publications@Marquette. Elsevier does not grant permission for this article to be further copied/distributed or hosted elsewhere without the express permission from Elsevier. 
Bloch et al., 2000.M. Bloch, P.J. Schmidt, M. Danaceau, J. Murphy, L. Nieman, D.R. Rubinow. Effects of gonadal steroids in women with a history of postpartum depression. Am. J. Psychiatry, 157 (2000), pp. 924-930

Bloch et al., 2005. M. Bloch, D.R. Rubinow, P.J. Schmidt, A. Lotsikas, G.P. Chrousos, G. Cizza. Cortisol response to ovine corticotropin-releasing hormone in a model of pregnancy and parturition in euthymic women with and without a history of postpartum depression. J. Clin. Endocrinol. Metab., 90 (2005), pp. 695-699

Boufidou et al., 2009. F. Boufidou, I. Lambrinoudaki, J. Argeitis, I.M. Zervas, P. Pliatsika, A.A. Leonardou, G. Petropoulos, D. Hasiakos, K. Papadias, C. Nikolaou. CSF and plasma cytokines at delivery and postpartum mood disturbances. J. Affect. Disord., 115 (2009), pp. 287-292

Chapwanya et al., 2012. A. Chapwanya, K.G. Meade, C. Foley, F. Narciandi, A.C. Evans, M.L. Doherty, J.J. Callanan, C. O'Farrelly. The postpartum endometrial inflammatory response: a normal physiological event with potential implications for bovine fertility. Reprod. Fertil. Dev., 24 (2012), pp. 1028-1039

Charmandari et al., 2005. E. Charmandari, C. Tsigos, G. Chrousos. Endocrinology of the stress response. Annu. Rev. Physiol., 67 (2005), pp. 259-284

Chaudron et al., 2010. L.H. Chaudron, P.G. Szilagyi, W. Tang, E. Anson, N.L. Talbot, H.I. Wadkins, X. Tu, K.L. Wisner. Accuracy of depression screening tools for identifying postpartum depression among urban mothers. Pediatrics, 125 (2010), pp. e609-e617

Christiaens et al., 2008. I. Christiaens, D.B. Zaragoza, L. Guilbert, S.A. Robertson, B.F. Mitchell, D.M. Olson. Inflammatory processes in preterm and term parturition. J. Reprod. Immunol., 79 (2008), pp. $50-57$

Christian and Porter, 2014. L.M. Christian, K. Porter. Longitudinal changes in serum proinflammatory markers across pregnancy and postpartum: effects of maternal body mass index. Cytokine (2014)

Chrousos, 1995. G.P. Chrousos. The hypothalamic-pituitary-adrenal axis and immune-mediated inflammation. New Engl. J. Med., 332 (1995), pp. 1351-1362

Chrousos et al., 1998. G.P. Chrousos, D.J. Torpy, P.W. Gold. Interactions between the hypothalamic-pituitary-adrenal axis and the female reproductive system: clinical implications. Ann. Intern. Med., 129 (1998), pp. 229-240

Cohen et al., 1983. S. Cohen, T. Kamarck, R. Mermelstein. A global measure of perceived stress. J. Health Soc. Behav., 24 (1983), pp. 385-396

Corwin et al., 2003. E.J. Corwin, L.E. Murray-Kolb, J.L. Beard. Low hemoglobin level is a risk factor for postpartum depression. J. Nutr., 133 (2003), pp. 4139-4142

Brain, Behavior, and Immunity, Vol 49 (October 2015): pg. 86-93. DOI. This article is (C) Elsevier and permission has been granted for this version to appear in e-Publications@Marquette. Elsevier does not grant permission for this article to be further copied/distributed or hosted elsewhere without the express permission from Elsevier. 
Corwin et al., 2005. E.J. Corwin, J. Brownstead, N. Barton, S. Heckard, K. Morin. The impact of fatigue on the development of postpartum depression. JOGNN, 34 (2005), pp. 577-586

Corwin et al., 2008. E.J. Corwin, N. Johnston, L. Pugh. Symptoms of postpartum depression associated with elevated levels of interleukin-1 beta during the first month postpartum. Biol. Res. Nurs., 10 (2008), pp. $128-133$

Corwin et al., 2013. E.J. Corwin, Y. Guo, K. Pajer, N. Lowe, D. McCarthy, S. Schmiege, M. Weber, T. Pace, B. Stafford. Immune dysregulation and glucocorticoid resistance in minority and low income pregnant women. Psychoneuroendocrinology (2013)

Costas et al., 2010. J. Costas, M. Gratacos, G. Escaramis, R. Martin-Santos, Y. de Diego, E. Baca-Garcia, F. Canellas, X. Estivill, R. Guillamat, M. Guitart, et al. Association study of 44 candidate genes with depressive and anxiety symptoms in post-partum women. J. Psychiatr. Res., 44 (2010), pp. 717-724

Cox et al., 1987. J.L. Cox, J.M. Holden, R. Sagovsky. Detection of postnatal depression. Development of the 10-item Edinburgh postnatal depression scale. Br. J. Psychiatry, 150 (1987), pp. 782-786

Dantzer and Kelley, 2007.R. Dantzer, K.W. Kelley. Twenty years of research on cytokine-induced sickness behavior. Brain Behav. Immun., 21 (2007), pp. 153-160

Dennis and Dowswell, 2013. C.L. Dennis, T. Dowswell. Psychosocial and psychological interventions for preventing postpartum depression. Cochrane Database Syst. Rev., 2 (2013), p. CD001134

Elenkov, 2008. I.J. Elenkov. Neurohormonal-cytokine interactions: implications for inflammation, common human diseases and wellbeing. Neurochem. Int., 52 (2008), pp. 40-51

Elenkov et al., 2005. I.J. Elenkov, D.G. Iezzoni, A. Daly, A.G. Harris, G.P. Chrousos. Cytokine dysregulation, inflammation and well-being. NeuroImmunoModulation, 12 (2005), pp. 255-269

Field, 2010. T. Field. Postpartum depression effects on early interactions, parenting, and safety practices: a review. Infant Behav. Dev., 33 (2010), pp. 1-6

Figueira et al., 2010. P. Figueira, L. Malloy-Diniz, S.B. Campos, D.M. Miranda, M.A. Romano-Silva, L. De Marco, F.S. Neves, H. Correa. An association study between the Val66Met polymorphism of the BDNF gene and postpartum depression. Arch. Women Ment. Health, 13 (2010), pp. 285-289

Fredericks et al., 2010. C.A. Fredericks, E.M. Drabant, M.D. Edge, J.M. Tillie, J. Hallmayer, W. Ramel, J.R. Kuo, S. Mackey, J.J. Gross, F.S. Dhabhar. Healthy young women with serotonin transporter SS polymorphism

Brain, Behavior, and Immunity, Vol 49 (October 2015): pg. 86-93. DOI. This article is @ Elsevier and permission has been granted for this version to appear in e-Publications@Marquette. Elsevier does not grant permission for this article to be further copied/distributed or hosted elsewhere without the express permission from Elsevier 
show a pro-inflammatory bias under resting and stress conditions.

Brain Behav. Immun., 24 (2010), pp. 350-357

Gavin et al., 2005. N.I. Gavin, B.N. Gaynes, K.N. Lohr, S. Meltzer-Brody, G. Gartlehner, T. Swinson. Perinatal depression: a systematic review of prevalence and incidence. Obstet. Gynecol., 106 (2005), pp. 10711083

Glynn et al., 2013. L.M. Glynn, E.P. Davis, C.A. Sandman. New insights into the role of perinatal HPA-axis dysregulation in postpartum depression. Neuropeptides, 47 (2013), pp. 363-370

Goshtasebi et al., 2013. A. Goshtasebi, M. Alizadeh, S.B. Gandevani. Association between maternal anaemia and postpartum depression in an urban sample of pregnant women in Iran. J. Health Popul. Nutr., 31 (2013), pp. 398-402

Groer and Morgan, 2007. M.W. Groer, K. Morgan. Immune, health and endocrine characteristics of depressed postpartum mothers.

Psychoneuroendocrinology, 32 (2007), pp. 133-139

Guilbaud et al., 2009. O. Guilbaud, F. Curt, C. Perrin, G. Chaouat, S. Berthoz, C.D.L. Bigre, J. Wallier, M. Strebler, C. Touitou, P. Jeammet, M. Corcos. Decreased immune response in alexithymic women: a crosssectional study. Biomed. Pharmacother., 63 (2009), pp. 297-304

Guintivano et al., 2013. J. Guintivano, M. Arad, T.D. Gould, J.L. Payne, Z.A. Kaminsky. Antenatal prediction of postpartum depression with blood DNA methylation biomarkers. Mol. Psychiatry (2013)

Hay et al., 2008. D.F. Hay, S. Pawlby, C.S. Waters, D. Sharp. Antepartum and postpartum exposure to maternal depression: different effects on different adolescent outcomes. J. Child Psychol. Psychiatry, 49 (2008), pp. $1079-1088$

Hebisch et al., 2004. G. Hebisch, P.M. Neumaier-Wagner, R. Huch, U. von Mandach. Maternal serum interleukin- 1 beta, -6 and -8 levels and potential determinants in pregnancy and peripartum. J. Perinat. Med., 32 (2004), pp. 475-480

Hojilla et al., 2011. C.V. Hojilla, H.W. Jackson, R. Khokha. TIMP3 regulates mammary epithelial apoptosis with immune cell recruitment through differential TNF dependence. PLOS ONE, 6 (2011)

Kalantaridou et al., 2010. S.N. Kalantaridou, E. Zoumakis, A. Makrigiannakis, L.G. Lavasidis, T. Vrekoussis, G.P. Chrousos. Corticotropin-releasing hormone, stress and human reproduction: an update. J. Reprod. Med., 85 (2010), pp. 33-39

Kimmel et al., 2013. M. Kimmel, Z. Kaminsky, J.L. Payne. Biomarker or pathophysiology? The role of DNA methylation in postpartum depression. Epigenomics, 5 (2013), pp. 473-475

Le Donne et al., 2012. M. Le Donne, S. Settineri, S. Benvenga. Early pospartum alexithymia and risk for depression: relationship with

Brain, Behavior, and Immunity, Vol 49 (October 2015): pg. 86-93. DOI. This article is (C) Elsevier and permission has been granted for this version to appear in e-Publications@Marquette. Elsevier does not grant permission for this article to be further copied/distributed or hosted elsewhere without the express permission from Elsevier. 
serum thyrotropin, free thyroid hormones and thyroid autoantibodies.

Psychoneuroendocrinology, 37 (2012), pp. 519-533

Maes et al., 2000. M. Maes, A.H. Lin, W. Ombelet, K. Stevens, G. Kenis, R. De Jongh, J. Cox, E. Bosmans. Immune activation in the early puerperium is related to postpartum anxiety and depressive symptoms.

Psychoneuroendocrinology, 25 (2000), pp. 121-137

Maes et al., 2002. M. Maes, R. Verkerk, S. Bonaccorso, W. Ombelet, E.

Bosmans, S. Scharpe. Depressive and anxiety symptoms in the early puerperium are related to increased degradation of tryptophan into kynurenine, a phenomenon which is related to immune activation. Life Sci., 71 (2002), pp. 1837-1848

Mastorakos and Ilias, 2003. G. Mastorakos, I. Ilias. Maternal and fetal hypothalamic-pituitary-adrenal axes during pregnancy and postpartum. Ann. N. Y. Acad. Sci., 997 (2003), pp. 136-149

Miller et al., 1999. A.H. Miller, C.M. Pariante, B.D. Pearce. Effects of cytokines on glucocorticoid receptor expression and function. Glucocorticoid resistance and relevance to depression. Adv. Exp. Med. Biol., 461 (1999), pp. 107-116

Miller et al., 2002. G.E. Miller, S. Cohen, A.K. Ritchey. Chronic psychological stress and the regulation of pro-inflammatory cytokines: a glucocorticoid-resistance model. Health Psychol., 21 (2002), pp. 531541

Miller et al., 2008. G.E. Miller, E. Chen, J. Sze, T. Marin, J.M. Arevalo, R. Doll, R. Ma, S.W. Cole. A functional genomic fingerprint of chronic stress in humans: blunted glucocorticoid and increased NF-kappaB signaling. Biol. Psychiatry, 64 (2008), pp. 266-272

Miller et al., 2009. G.E. Miller, E. Chen, A.K. Fok, H. Walker, A. Lim, E.F. Nicholls, S. Cole, M.S. Kobor. Low early-life social class leaves a biological residue manifested by decreased glucocorticoid and increased proinflammatory signaling. Proc. Natl. Acad. Sci. U.S.A., 106 (2009), pp. 14716-14721

Mor and Cardenas, 2010. G. Mor, I. Cardenas. The immune system in pregnancy: a unique complexity. Am. J. Reprod. Immunol., 63 (2010), pp. 425-433

Nilsen-Hamilton et al., 2003. M. Nilsen-Hamilton, Q. Liu, J. Ryon, L. Bendickson, P. Lepont, Q. Chang. Tissue involution and the acute phase response. Ann. N. Y. Acad. Sci., 995 (2003), pp. 94-108

O'Keane et al., 2011. V. O'Keane, S. Lightman, K. Patrick, M. Marsh, A.S. Papadopoulos, S. Pawlby, G. Seneviratne, A. Taylor, R. Moore. Changes in the maternal hypothalamic-pituitary-adrenal axis during the early puerperium may be related to the postpartum 'Blues'. $J$. Neuroendocrinol., 23 (2011), pp. 1149-1155

Brain, Behavior, and Immunity, Vol 49 (October 2015): pg. 86-93. DOI. This article is (C) Elsevier and permission has been granted for this version to appear in e-Publications@Marquette. Elsevier does not grant permission for this article to be further copied/distributed or hosted elsewhere without the express permission from Elsevier 
Okun et al., 2011. M.L. Okun, J. Luther, A.A. Prather, J.M. Perel, S. Wisniewski, K.L. Wisner. Changes in sleep quality, but not hormones predict time to postpartum depression recurrence. J. Affect. Disord., 130 (2011), pp. 378-384

Osborne and Monk, 2013. L.M. Osborne, C. Monk. Perinatal depression-the fourth inflammatory morbidity of pregnancy? Theory and literature review. Psychoneuroendocrinology, 38 (2013), pp. 1929-1952

Pace and Miller, 2009. T.W. Pace, A.H. Miller. Cytokines and glucocorticoid receptor signaling. Relevance to major depression. Ann. N. Y. Acad. Sci., 1179 (2009), pp. 86-105

Pace et al., 2012. T.W. Pace, K. Wingenfeld, I. Schmidt, G. Meinlschmidt, D.H. Hellhammer, C.M. Heim. Increased peripheral NF-kappaB pathway activity in women with childhood abuse-related posttraumatic stress disorder. Brain Behav. Immun., 26 (2012), pp. 13-17

Pearson et al., 2013. R.M. Pearson, J. Evans, D. Kounali, G. Lewis, J. Heron, P.G. Ramchandani, T.G. O'Connor, A. Stein. Maternal depression during pregnancy and the postnatal period risks and possible mechanisms for offspring depression at age 18 years. JAMA Psychiatry, 70 (2013), pp. 1312-1319

Petrovsky, 2001. N. Petrovsky. Towards a unified model of neuroendocrineimmune interaction. Immunol. Cell Biol., 79 (2001), pp. 350-357

Petrovsky and Harrison, 1997. N. Petrovsky, L.C. Harrison. Diurnal rhythmicity of human cytokine production: a dynamic disequilibrium in T helper cell type $1 / T$ helper cell type 2 balance? J. Immunol., 158 (1997), pp. 5163-5168

Pruessner et al., 2003. J.C. Pruessner, C. Kirschbaum, G. Meinlschmid, D.H. Hellhammer. Two formulas for computation of the area under the curve represent measures of total hormone concentration versus timedependent change. Psychoneuroendocrinology, 28 (2003), pp. 916931

Raison and Miller, 2013. C.L. Raison, A.H. Miller. Malaise, melancholia and madness: the evolutionary legacy of an inflammatory bias. Brain Behav. Immun., 31 (2013), pp. 1-8

Raison et al., 2006. C.L. Raison, L. Capuron, A.H. Miller. Cytokines sing the blues: inflammation and the pathogenesis of depression. Trends Immunol., 27 (2006), pp. 24-31

Ruiz et al., 2003. R.J. Ruiz, J. Fullerton, D.J. Dudley. The interrelationship of maternal stress, endocrine factors and inflammation on gestational length. Obstet. Gynecol. Surv., 58 (2003), pp. 415-428

Salamonsen, 2003. L.A. Salamonsen. Tissue injury and repair in the female human reproductive tract. Reproduction, 125 (2003), pp. 301-311

Brain, Behavior, and Immunity, Vol 49 (October 2015): pg. 86-93. DOI. This article is (C) Elsevier and permission has been granted for this version to appear in e-Publications@Marquette. Elsevier does not grant permission for this article to be further copied/distributed or hosted elsewhere without the express permission from Elsevier. 
Shelton et al., 2014. M.M. Shelton, D.L. Schminkey, M.W. Groer. Relationships among prenatal depression, plasma cortisol and inflammatory cytokines. Biol. Res. Nurs. (2014)

Steptoe et al., 2007. A. Steptoe, M. Hamer, Y. Chida. The effects of acute psychological stress on circulating inflammatory factors in humans: a review and meta-analysis. Brain Behav. Immun., 21 (2007), pp. 901912

Taraz et al., 2012. M. Taraz, M.R. Khatami, A. Gharekhani, A. Abdollahi, H. Khalili, S. Dashti-Khavidaki. Relationship between a pro- and antiinflammatory cytokine imbalance and depression in haemodialysis patients. Eur. Cytokine Netw., 23 (2012), pp. 179-186

Teissedre and Chabrol, 2004. F. Teissedre, H. Chabrol. A study of the Edinburgh postnatal depression scale (EPDS) on 859 mothers: detection of mothers at risk for postpartum depression. Encephale, 30 (2004), pp. 376-381

Tsigos and Chrousos, 2002. C. Tsigos, G.P. Chrousos. Hypothalamicpituitary-adrenal axis neuroendocrine factors and stress. $J$. Psychosom. Res., 53 (2002), pp. 865-871

Vitoratos et al., 2006. N. Vitoratos, D.C. Papatheodorou, S.N. Kalantaridou, G. Mastorakos. "Reproductive" corticotropin-releasing hormone. Ann. N. Y. Acad. Sci., 1092 (2006), pp. 310-318

Watkins et al., 1999. L.R. Watkins, K.T. Nguyen, J.E. Lee, S.F. Maier. Dynamic regulation of proinflammatory cytokines. Adv. Exp. Med. Biol., 461 (1999), pp. 153-178

Wisner et al., 2010. K.L. Wisner, E.L. Moses-Kolko, D.K.Y. Sit. Postpartum depression: a disorder in search of a definition. Arch. Women Ment. Health, 13 (2010), pp. 37-40

Yang and Glaser, 2002. E.V. Yang, R. Glaser. Stress-induced immunomodulation and the implications for health. Int. Immunopharmacol., 2 (2002), pp. 315-324

Yim et al., 2009. I.S. Yim, L.M. Glynn, C. Dunkel-Schetter, C.J. Hobel, A. Chicz-DeMet, C.A. Sandman. Risk of postpartum depressive symptoms with elevated corticotropin-releasing hormone in human pregnancy. Arch. Gen. Psychiatry, 66 (2009), pp. 162-169

Brain, Behavior, and Immunity, Vol 49 (October 2015): pg. 86-93. DOI. This article is (C) Elsevier and permission has been granted for this version to appear in e-Publications@Marquette. Elsevier does not grant permission for this article to be further copied/distributed or hosted elsewhere without the express permission from Elsevier. 